\section{APP-109 前立腺癌 $\mathrm{pN}$ 診断におけるリンパ節数 の影響}

\section{福岡大学筑紫病院泌尿器科}

石井 龍, 古賀 洋介, 大西 弘重, 平 浩志, 平塚 義治 【目的】前立腺癌における正確な $\mathrm{pN}$ 診断のために最低限 必要なリンパ節の数は 13 個とする報告がある.そのこと を検証する目的でリンパ節の数と転移の関連について検 討した【対象と方法】対象は術前内分泌療法をしていな い根治的前立腺全摘除術施行例 97 例.リンパ節郭清の轮 囲は内・外腸骨と閉鎖で，リンパ節の最大割面で作製し た組織標本を用いてリンパ節の数，大きさ $($ 最大短径) と 転移の有無を集計.リンパ節数によって A 群（12 個以 下) と B 群 (13 個以上) の 2 群に分類し, 術前 PSA 值, $\mathrm{pN} 1$ 症例の割合, リンパ節の大きさの分布を比較. [結 果】 A 群 (33 例) と B 群 (64 例) において, 術前 PSA 值（平均 $\pm \mathrm{SD} \mathrm{ng} / \mathrm{ml}$ ）は，それぞれ $15.3 \pm 11.8$ と $11.5 \pm$ 11.8 で有意差なし. pN1 症例はそれぞれ $6.1 \%$ と $12.5 \%$ と A 群で少なかったが有意差はなし.大きさの分布では 径 1 4mm の小さなリンパが A 群で有意に少なかった $(\mathrm{p}<0.05)$. 一方, 10 例の $\mathrm{pN} 1$ 症例から得た 16 個の転移 リンパ節の大きさは，平均 $3.8 \mathrm{~mm}, 16$ 個中 13 個 $(81 \%)$ は $4 \mathrm{~mm}$ 以下のリンパ節であった.【結論】リンパ節の少 ない症例で $\mathrm{pN} 1$ が少ない原因の 1 つとして, 小さいリン パ節の検出が不十分となり正確な $\mathrm{pN}$ 診断ができていな い可能性が示唆された.

\section{APP-110 姫路市およびその周边地域の前立腺洁}

Himeji St.Mary's Hospital', 国立姬路医療センター ${ }^{21}$, 新 日鉄広烟病院 ${ }^{3)}$, 姬路赤十字病院 ${ }^{4)}$

真弓 友介 ${ }^{12}$, 野田 雅俊 ${ }^{12}$, 橋村 孝幸 ${ }^{21}$, 白波瀬 敏明 ${ }^{21}$, 山崎 俊成 ${ }^{2)}$, 仲島 義治 ${ }^{2}$, 藤井 明 ${ }^{32}$, 松本 弘人 ${ }^{32}$, 造住 誠孝 ${ }^{3}$, 小川 隆義音, 岡本 雅之 ${ }^{4)}$, 楠田 雄司 ${ }^{4)}$ 我々は 1994 年から姫路市およびその周辺(神崎郡、飾磨郡、宾栗郡、朝 来郡、佐用郡、童野市) にお汁る前立腺㾔を集計し、前立腺癌の疫学的 動向を换討している。男性人口就 38 万人、50藏以上の男性人口は 11 万 2 千人である。9 94 年から 2000 年までの 10 年間に前立腺㾔と診断さ れた患者数は、1077 例であるが、2000年を境に急增しており2003年は 231 例と著明に增加していた。2000年を境に変化している部分に目を向 けると、集団検診からの紹介症例、かかりつけ医にてPSAを測定して高 值であった症例、PSA の高值を主訴とする症例、PSA の比較的低值症 例、Stage B(特に Stage B0)症例などが增加する佰向が見られた。市部、 郡部で增加率に差はなかった。また 1998 年より集計に組み入れた患者 の紹介率は年タ增加しているが、2003年には $73 \%$ と過去最高になっ た。これらは泌层器科以外の医療機関や一般市民の間に前立腺癌や PSA 検查に対する意識がさらに高まり、98年頃より始まった前立腺癌 検診が规模を拡大して行われるようになり、PSA 高値の患者が多数紹 介されていることによると考えられた。患者の年齢層は 70 代が最も多 く注は半数を占め、60代、80 代の順であったが、一方で 50 代の患者も 55 例 $(5.1 \%)$ みられた。集計も10 年を超元、過去の症例の追跡調查も 行っているが、5年生存率 $69.2 \% 、 50 \%$ 生存期間梳 99.1 ケ月であった。

\section{APP-111 前立腺癌模診 リピーターについての 解析}

\section{広島大学大学院医歯薬学総合研究科堅泌尿器科学 \\ 安本 博晃, 松原 昭郎, 三田 耕司, 亭島 淳,}

望月 英樹, 石 光広, 碓井 亞

【目的】 2002 年、 2003 年に実施した前立腺癌検診で 2 年 連続受検した、いわゆるりピーターの特徽を解析する。 【対象と方法】広島県備北地域の前立腺癌検診受診者 4185 人 (平均 67.5 歳) 中、 2002 年、 2003 年と連続して受 診した 1908 人を対象とし、初年度 PSA 值、次年度 PSA 值、PSA 增加速度について解析した。結果】初年度一次 検診陽性者 132 人中 98 人 $(74 \%)$ が次年度も一次検診陽 性で、そのうち二次検診を受診した 55 人中 10 人（初年 度一次検診陽性者の 7.5\%)に癌を認めた。PSA 增加速度 は、癌陽性群が $1.84 \pm 1.4 \mathrm{ng} /$ year であり、癌陰性群の $0.61 \pm 3.7 \mathrm{ng} /$ year に比較して有意に高かった $(\mathrm{p}<0.01)$ 。 初年度一次検診㓌性者 1776 人中の次年度一次検診陽性 者は 37 人 $(2 \%)$ であり、二次検診を受診した 33 人中 6 人（初年度一次検診陰性者の $0.3 \%$ ) に癌を認めた。PSA 增加速度は癌陽性群で $1.34 \pm 0.5 \mathrm{ng} /$ year、癌陰性群で $2.05 \pm 2.2 \mathrm{ng} /$ year であったが両者の増加率に有意差を認 めなかった。結語】初年度一次検診陽性者の次年度癌陽 性率は高率である。初年度一次検診が陰性の場合、癌陽 性の予測に PSA 増加速度の有用性は低い

\section{APP-112 前立腺洁スクリーニングにおけるベー スラインPSAによる検診間隔設定モ デル}

\section{浜松労災病院泌尿器科", 京都大学大学院経消学研究 科・日本学術振興会特別研究員 ${ }^{2)}$}

小林 恭" ${ }^{1}$, 後藤 励 ${ }^{2}$, 河原 貴史 ${ }^{11}$, 光森 健二 ${ }^{1}$

【背景と目的】前立腺澏集団検診における re-screening interval 生 初年度のベースライン PSA 值(以下 PSA)によって決定すべきとの 報告が見られる。今回我々は Decision-analytic model を用いてこの 問題を検討した。対象と方法]実際の集団検診の結果を基に検診参 加者のベースライン PSA をステータスの基準とする前立腺癌集団 検診に関する Markov model を作成し Quality-adjusted life years （QALY）あたりの費用（cost-effectiveness）を検討した。結果了検 診開始時 50 歳のコホート集団の 5 年後の癌検出率は $0.96 \%$ であっ た。PSA $\leqq 2.0 \mathrm{ng} / \mathrm{ml}$ なら隔年検診、>2.0なら毎年検診とする方針が 最も費用対効果比が優れていた。感度分析の結果、PSA 值にかかわ らず每年検診を行う方針は 2 次検診受診率や生検における癌検出 率が高いあるいはPSA 検査費用の低い条件下で、さらに 60 代の 受診者に扔いて一部隔年検診の方針に比べて Incremental cost-effectiveness ratioが低くなる傾向が見られた。まとめ】前立腺癌検 診における最適な検診間隔を PSA 值 $0.0 \sim 2.0 \mathrm{ng} / \mathrm{ml}$ の範囲にカッ トオフを設定し隔年とすることの妥当性が、費用効果分析からも示 唆された。実際のカットオフ值に関しては各々の集団における2 次㛟診受診率・生検にお汀る癌検出率・PSA 検查費用・受診者の 年龄等を考慮に入れて決定すべきであると考えられた。 